\title{
The library-faculty partnership in curriculum development
}

\author{
By John A. Lanning \\ Department of Chemistry \\ University of Colorado at Denver
}

\section{A paper delivered at the ACRL President's Program in San Francisco, June 29, 1987.}

$I_{t}$ t is fair to ask why a chemist is discussing libraryfaculty partnerships, particularly a chemist with little formal training in library science. As a faculty member interested in curriculum development, I see library science, or information literacy, central to new directions in curriculum development. Furthermore, I have been teaching a course entitled "Chemical Literature" for approximately ten years, the last five of which have been a team effort between myself and a science librarian.

From this background I will ask you to look at curriculum development as a joint library-faculty partnership. It is necessary to note that my views are from a fairly limited exposure to library personnel and policies.

Before discussing any change in the libraryfaculty relationship, it is necessary to review the current relationship between faculty and librarians. I characterize this relationship as distant, ineffective, and often driven by frustration. There are several reasons why such a poor relationship currently exists.

- Many, if not most, faculty consider only the service role of librarians. This results in a relationship where faculty consider librarians more as subservient staff rather than academic colleagues.

- Faculty do not understand the multitude of responsibilities carried out by librarians. While fac- ulty are responsible to many students in a single discipline, librarians must serve as liaison to a very large number of faculty and students over a variety of disciplines.

- Faculty too often dwell on the frustrations of not having journals and monographs for their research and teaching projects.

- Librarians tend to concentrate on the frustrations of not having faculty solicit their experience and expertise.

- A close working relationship between faculty and librarians is difficult with the large turnover in personnel often encountered in academic institutions.

Although I have painted a rather bleak picture for library-faculty relationships, this need not be the case. Indeed this is the right time to foster a working relationship between faculty and librarians for the purpose of curriculum development.

My view of curriculum development may be a little different than you are used to hearing. I see very few truly innovative and successful curriculum changes in higher education and a tendency for curriculum development to play "follow the leader." Many "new" curricula are adaptations of older systems which have just been repackaged to confuse faculty and students alike. The change from quarter to semester system, the adoption of 
pass-fail grades, and the proliferation of plusminus grading systems have to some extent spread across the United States as one campus tries to keep up with another.

Nevertheless, there are currently two areas of change in higher education which are having a dramatic influence on curriculum development and towards which faculty and librarians must work together in order to influence a proper direction of curriculum development.

The first area of curriculum development comes under the heading of education assessment. State legislatures and governing boards of private institutions are increasingly finding it politically beneficial to hold higher education accountable for the large amount of funds invested. That is, do students learn anything for the dollars invested in their education? States such as Tennessee are leading this movement, while others including Colorado have already passed legislation which mandate a process of education outcome assessment. How can one quantify an increase in educational skills? There are either no or many answers to this question, and most states are leaving the assessment methodology up to the institutions. I believe that library skills should be an important component in any education assessment system.

\section{Summer Research Fellowships in American history and culture}

The Historical Society of Pennsylvania and the Library Company of Philadelphia will again be holding their joint program of summer fellowships for 1988. The fellowships are solely for the support of research in the collections of these two libraries. Applications are welcomed in any relevant field of scholarship, from traditional aspects of American history to bibliography, the history of the book, and historical editing. The project proposal should demonstrate that these collections contain primary sources central to the research topic. Candidates are encouraged to inquire about the appropriateness of a proposed topic before applying.

The fellowships, which are tenable for one month from June to September, carry stipends of $\$ 1,000$. Fellows will be assisted in finding reasonably priced accommodations. While the program is designed for scholars possessing a $\mathrm{Ph}$.D. or a significant record of professional experience and scholarly publication, several fellowships will be reserved for doctoral candidates doing dissertation research.

Candidates must apply by February 1, 1988; appointments will be made by March 15, 1988 . To apply, send a vita, the names of three references, and a short description of your proposed project to: James Green, Curator, Library Company of Philadelphia, 1314 Locust St., Philadelphia, PA 19107; (215) 546-3181.
Since few students enter college with even rudimentary information literacy skills, colleges and universities should place a strong emphasis on the development of these skills. My experience in the chemical literature course indicates that senior undergraduate students have poor library skills, a fact that is easily quantified with a brief examination. Librarians and faculty must seek a partnership to mold curriculum development and the resulting education assessment with an information skills component. Whether the assessment methodology is a standardized examination at the end of the sophomore year or a senior-level seminar program, information literacy must play an important role.

The second area of development is that of core curriculum or general education requirements. The liberal arts and sciences colleges have a core curriculum to ensure a broad educational background as the cornerstone of life-long learning skills. This concept is being expanded to an institution level where each student, regardless of college or major, must satisfy $35-50$ semester hours of general education requirements. Mandatory courses in English, speech, and mathematics are common components of the new core curriculum requirements.

Core curriculum courses have at least two distinct goals: to provide elements for critical thinking and to integrate diverse educational backgrounds. Information literacy skills are essential to both goals. The library should be a classroom for core curriculum courses.

I see two possibilities for library-faculty participation in the core curriculum development. First, a freshman-sophomore level course in general library science skills. This is best taught by librarians in the library. The library personnel resources necessary to teach large numbers of students must be considered. Self-paced, audiovisual, or computerassisted courses may be considered in lieu of traditional lecture courses. Second, a junior-senior level course taught in a narrow range of specific disciplines. The chemical literature course at $\mathrm{CU}$ Denver is an example of this approach. I strongly believe that the best way to teach this type of course is a partnership between librarian and faculty member. From my experience, teaching a course in this manner is rewarding for students and challenging for instructors. I receive more praise from chemistry graduates on the chemical literature component of their education than anything I do strictly in chemistry. Graduates quickly recognize the importance of information literacy skills specific to their professional training.

If, as I have portrayed, information skills are important to curriculum development and if, as I believe, a strong library-faculty partnership is the best way to achieve proper curriculum development, how can the library-faculty partnership be improved? I suggest the following general approaches.

-Efforts should be directed to increase the dia- 


\section{The Price Went Up AGAIN?}

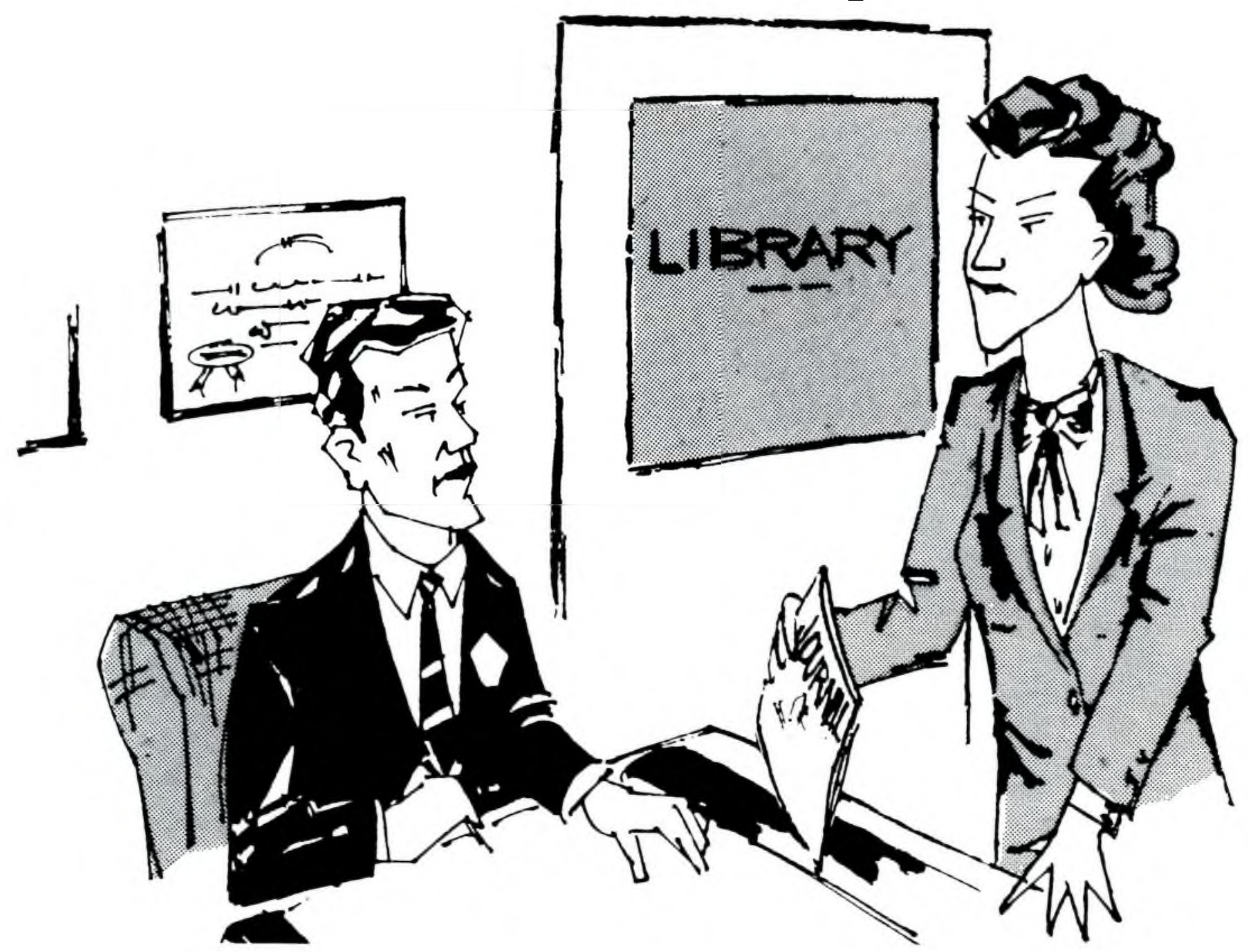

I've got a better idea. Instead of resubscribing, let's split the money and each of us buy a Ferrari!

Yes, subscription costs are going up, and probably faster than your budget. Fortunately, Materials Information ${ }^{\circledR}$ has some tools to help you deal with price leaps, such as Metals Abstracts ${ }^{\circledR}$ and Engineered Materials Abstracts ${ }^{\text {TM }}$.

Do your patrons need to keep up with progress in metals or materials? Rather than scanning the contents pages of ten or twenty journals, they can skim the abstracts in MA or EMA, and cover about 2,000 . Our informative abstracts will let them choose only the material they really need.

Is your online budget as predictable as a horse race? The print versions of Metals Abstracts ${ }^{\circledR}$ and Engineered Materials Abstracts ${ }^{\text {TM }}$ mean only one invoice per year, at a known cost. In addition, abstracts journals do not require special equipment or training to use. Your patrons can search on their own and let you make better use of your time.

If you'd like to know more about how Materials Information can help you cope with price leaps, call (216) 338-5151, ext. 554, and ask for your FREE copy of our 1988 catalog.

Metals Abstracts ${ }^{\circledR}$ and Engineered Materials Abstracts ${ }^{\top \mathrm{MM}}$. In an age of rising prices, it's good to know that there are still real values. 
logue between librarian and faculty member. There should be at least one faculty member in each department who recognizes the importance of information literacy skills.

- Many departments are accredited on a regular basis by national organizations such as the American Chemical Society for chemistry departments. Librarians should become familiar with library skills suggested or required by accrediting agencies in order to facilitate better relationships with departments.

- Librarian and faculty member should work towards a common goal of curriculum development. The current campus discussions of education assessment and core curriculum requirements provide an excellent opportunity to integrate library and faculty skills in curriculum development.

- Administrators and directors must recognize the importance of information literacy skills as they apply towards curriculum development. Library personnel must be willing to serve on curriculum development committees and be vocal advocates for their points of view.

- The library and departments should seek novel approaches to common problems of limited resources and heavy work loads as they affect curriculum development.

- Librarians and faculty should seek opportunities to team teach a course on information literacy. This can be general literacy skills or discipline specific.

In this presentation I have portrayed a pessimistic picture of current library-faculty relationships. But more importantly, I have tried to indicate the dynamic nature of higher education curriculum development and the opportunity that a libraryfaculty partnership has in guiding such development. The synergism in a library-faculty partnership is waiting to be exploited.

I gratefully acknowledge three librarians who have had a very positive influence on my views of information literacy and faculty-library partnerships. Patricia Breivik is director of the Auraria Library for the University of Colorado at Denver, Betsy Porter is science librarian at the Auraria Library, and Beth Warner, a former science librarian at Auraria, is currently librarian at Louisiana State University.

\section{Teleconference on CD-ROM}

ACRL and CCAIT, the Community College Association for Instruction and Technology, will cosponsor TECHNO-COM, a national teleconference on the topic of CD-ROM technology on Wednesday, April 27, 1988. Originating from the studios of Oakton Community College, Des Plaines, Illinois, it will air from 11:00 a.m. to 1:00 p.m., CST.

Moderator for TECHNO-COM will be Nancy Melin Nelson, editor of CD-ROM Librarian, author of Library Applications of Optical Disk and CD-ROM Technology, and contributing editor to CD-ROM Review and Optical Information Systems.

The teleconference will feature vendor presentations of representative CD-ROM products which currently provide: public access catalogs; reference and collection development tools; library and financial services; cataloging support; and major online databases.

Intended especially for library and LRC personnel, TECHNO-COM will:

- supply an overview of CD-ROM technology and CD-ROM workstations;

- provide in-depth information about available products and costs;

- present an overview of library receptivity to CD-ROM products;

- suggest a variety of uses for CD-ROM in library/LRC environments;
- address cost structures and implementation issues;

- outline the latest trends in CD-ROM product development and marketing;

-stimulate innovative uses of CD-ROM for instructional support;

- promote the participation of library/LRC professionals in sharing the future of this exciting information technology.

Institutions can register as receive sites for $\$ 50$ through February 1, 1988 (\$100 after that date). The fee entitles them to: ten participant packets; videotaping rights; telephoning rights; and CBand reception. Information about the teleconference may be obtained from: Joseph Borowski, director of learning resources, Oakton Community College, and vice-president of CCAIT, 1600 East Golf Road, Des Plaines, IL 60016; (312) 635-1641.

Other members of the task force planning the teleconference are: Bernard Fradkin, dean of learning resources, College of DuPage, and presidentelect, CCAIT; Tom Zimanzl, president, CCAIT; Robert Burton, chair, Audiovisual Services, Oakton Community College; Eileen Dubin, director of library services, Stockton State College, and chair, ACRL/CJCLS; and Margaret Holleman, coordinator of library services, Pima Community College, and editor of Community \& Junior College Libraries. 


\section{When You Need an Answer, and You Need It Fast, and It Has to Be Right-Turn to}

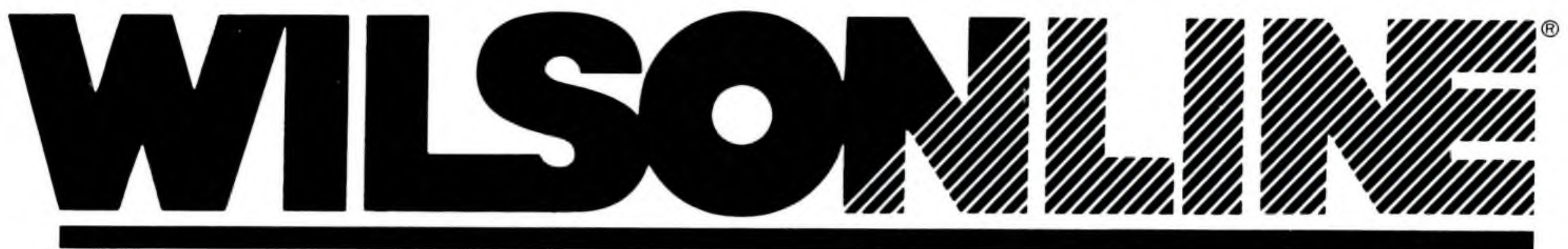

\section{ONLINE ACCESS TO THE WILSON INDEXES}

"Recommended for all libraries." - REFERENCE BOOKS BULLETIN

"A sophisticated search system that will impress searchers accustomed to the most advanced techniques." -DATABASE

\section{WILSONLINE-Recipient} of the 1985 Dartmouth Medal

\section{Current \\ Bibliographic Data}

Indexing everything from popular magazines to professional journals, WILSONLINE covers

- More than half a million articles in 3,500 periodicals each year

- 80,000 books annually

- 24,000 government publications annually

- More than 600,000 new records each year

- A total of more than 3 million records to date.

\section{Quality}

Updated at least twice each week, WILSONLINE databases contain the same dependable information as the familiar printed versions.

\section{Affordability}

WILSONLINE's pricing makes it affordable for more libraries than any comparable service. WILSONLINE becomes even more affordable when you add up the fees you don't have to pay: No start-up fee... No charge for saved searches... No royalty charges added to connect-time rates.

\section{User-Friendly}

\section{WILSONLINE Features}

- Up to 43 different access points to bibliographic records

- Searching of up to 8 databases simultaneously - Proximity searching - Nested Boolean logic - Automatic substitution of preferred form of subject headings and personal and corporate names - Free text searching

- Controlled vocabulary searching - A toll-free number for user assistance - Online help command and explain messages.

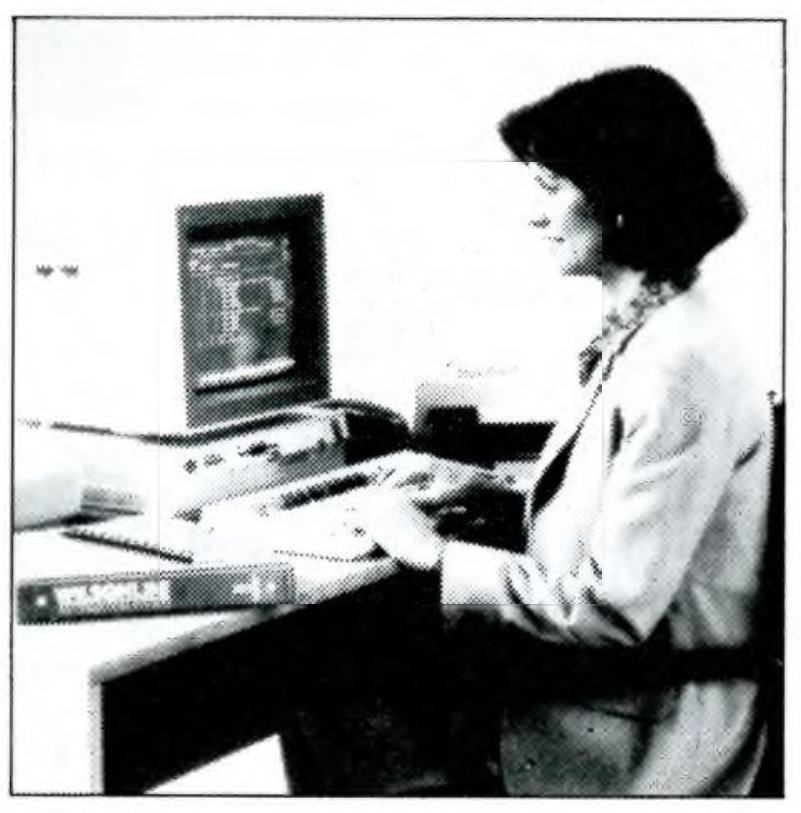

\section{WILSONLINE}

\section{Databases}

- Applied Science \& Technology Index • Art Index • Bibliographic Index - Biography Index

- Biological \& Agricultural Index - Book Review Digest - Business Periodicals Index $\bullet$ Cumulative Book Index • Education Index - Essay and General Literature Index - General Science Index - GPO Monthly Catalog

- Humanities Index • Index to Legal Periodicals • Index to U.S.

Government Periodicals

- LC/Foreign MARC File

- LC/MARC File - Library

Literature - MLA International Bibliography - Readers' Guide Abstracts - Readers' Guide to Periodical Literature - Social Sciences Index $\bullet$ Vertical File Index - Wilson Journal Directory

- Wilson Name Authority File

- Wilson Publishers Directory

\section{To Open Your} WILSONLINE Account Call Toll-Free:

\section{1-800-367-6770}

In New York State, call 1-800-462-6060 in Canada, call collect 212-588-8400.

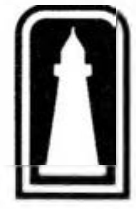

\section{THE H.W. WILSON COMPANY}

950 University Avenue Bronx, New York 10452 (212) 588-8400 